\title{
INTERPRETAÇÃO AMBIENTAL NO BIOMA DA CAATINGA: POTENCIALIDADES PARA O ECOTURISMO NO PARQUE NACIONAL DO CATIMBAU, BUÍQUE, PERNAMBUCO
}

Josângela da Silva Jesus

Elâine Maria dos Santos Ribeiro

Elba Maria Nogueira Ferraz

O ecoturismo em unidades de conservação tem se mostrado uma alternativa interessante para manejo do meio ambiente, principalmente aliado à educação ambiental, através da sensibilização dos visitantes e interpretação ambiental dos atrativos. O Parque Nacional do Catimbau, criado em 2002, encontra-se localizado no bioma da caatinga, entre o agreste e o sertão pernambucano, abrangendo os municípios de Buíque, Ibimirim e Tupanatinga. O parque apresenta um grande potencial para o desenvolvimento do ecoturismo através de suas trilhas e sítios arqueológicos, porém ainda não possui um plano de manejo, tampouco um programa de uso público. O Catimbau já recebe um bom número de visitações, que são realizadas com o acompanhamento de condutores que atuam através da Associação de Guias do Parque. Objetivando contribuir para o enriquecimento da experiência do visitante e para sua sensibilização quanto à importância do bioma da caatinga, este trabalho traz uma análise das potencialidades do Catimbau para a interpretação ambiental em trilhas e sugestões de como aproveitar adequadamente as oportunidades diagnosticadas. A pesquisa foi desenvolvida a partir do levantamento bibliográfico e documental de temas correlacionados e da área de estudo, 0 Parque, possibilitando o entendimento do seu funcionamento e sua relação com a atividade ecoturística. Foram realizadas visitas de campo, no período de 09 a 12 de fevereiro de 2006, onde foi possível levantar aspectos de interesse para a pesquisa e realizar registros fotográficos. Verificamos que os trabalhos desenvolvidos pelos condutores das trilhas do parque se limitam à simples exposição do espaço para os visitantes, sendo pouco aproveitada a riqueza vegetacional da caatinga, os sítios arqueológicos, dentre outros aspectos interessantes, para a sensibilização do turista. Com isso, propõe-se que seja estruturado um programa de interpretação e educação ambiental envolvendo gestores do parque e condutores locais a partir da sensibilização e capacitação dos mesmos, bem como a estruturação física das trilhas, através da implementação de placas indicativas e interpretativas. Desta forma, espera-se que além dos aspectos recreativos e de lazer fornecidos pela visitação, a interpretação ambiental seja verdadeiramente o objetivo de existência das atividades desenvolvidas no Parque, através do comprometimento dos condutores em relação à apresentação do ambiente de caatinga, demonstração de suas fragilidades e potenciais, atitudes adequadas a serem adotadas durante a visitação, como também promoção da satisfação do visitante.

Palavras Chaves: Unidades de conservação; Ecoturismo; Interpretação ambiental; Caatinga. 